MAROUELLI WA; SOUZA RB; BRAGA MB; SILVA WLC. 2014. Evaluation of sources, doses and application schedules of nitrogen on drip-irrigated tomato. Horticultura Brasileira 32: 327-335. DOI - http://dx.doi.org/10.1590/S0102-05362014000300015

\title{
Evaluation of sources, doses and application schedules of nitrogen on drip-irrigated tomato
}

\section{Waldir A Marouelli; Ronessa B Souza; Marcos B Braga; Washington LC Silva}

Embrapa Hortaliças, C. Postal 218,70351-970 Brasília-DF; waldir.marouelli@embrapa.br; ronessa.souza@embrapa.br; marcos.braga@ embrapa.br; wash.silva@uol.com.br

\begin{abstract}
We aimed to establish strategies for nitrogen $(\mathrm{N})$ fertilization on drip-irrigated determinate-growth-habit tomato, under Cerrado conditions of Central Brazil. Three field experiments were carried out in a randomized block design. In experiment I six $\mathrm{N}$ doses $(0,80$, $160,240,320$ and $400 \mathrm{~kg} \mathrm{ha}^{-1} \mathrm{~N}$ ) were tested, in experiment II six combinations of the $\mathrm{N}$ forms (nitric; ammonium; amide; $2 / 3$ nitric + $1 / 3$ ammonium; $2 / 3$ nitric $+1 / 3$ amide; and $1 / 3$ nitric $+2 / 3$ amide) were evaluated, and in experiment III the combination of three soil pre-plant fertilization fractions $(0,20$ and $40 \%)$ was evaluated with two splitting schemes of the remaining $\mathrm{N}$ via fertigation (linear and adjusted N-uptake curve). SPAD chlorophyll index and $\mathrm{N}$ content were measured in the leaves of tomato plants on experiment I. The physical and economic yields of tomato crop were maximized for the doses of $287 \mathrm{~kg} \mathrm{~N} \mathrm{ha}^{-1}$ and $270 \mathrm{~kg} \mathrm{~N} \mathrm{ha}^{-1}$, respectively, with doses of $2.1 \mathrm{~g}$ and $2.0 \mathrm{~g}$ of $\mathrm{N}$ per $\mathrm{kg}$ of commercial fruit. The yield was maximized for 52 SPAD units. The combinations of forms and the application schedules of $\mathrm{N}$ had no significant effect on the yield components of the tomato crop.
\end{abstract}

Keywords: Solanum lycopersicon, processing tomato, determinate growth, fertigation, nutritional status, economic analysis.

\section{RESUMO}

Avaliação de fontes, doses e estratégias de aplicação de nitrogênio em tomateiro irrigado por gotejamento

O objetivo deste trabalho foi estabelecer critérios para a fertilização nitrogenada do tomateiro de crescimento determinado irrigado por gotejamento, nas condições de Cerrado do Brasil Central. Foram conduzidos três ensaios com delineamento experimental em blocos ao acaso. No experimento I foram testadas seis doses de $\mathrm{N}(0,80$, $160,240,320$ e $\left.400 \mathrm{~kg} \mathrm{ha}^{-1}\right)$, no experimento II avaliaram-se seis combinações das formas de N (nítrica; amoniacal; amídica; 2/3 nítrica $+1 / 3$ amoniacal; $2 / 3$ nítrica $+1 / 3$ amídica; e $1 / 3$ nítrica $+2 / 3$ amídica) e no experimento III avaliou-se a combinação de três frações da dose total de $\mathrm{N}$ aplicadas em pré-plantio (0, 20 e 40\%) com dois esquemas de parcelamento do $\mathrm{N}$ restante via fertirrigação (linear e curva de absorção ajustada). O índice SPAD de clorofila e o teor de $\mathrm{N}$ foram determinados em folhas de tomateiro do experimento I. Os rendimentos físico e econômico do tomateiro atingiram o máximo para as doses de $\mathrm{N}$ de $287 \mathrm{~kg} \mathrm{ha}^{-1}$ e $270 \mathrm{~kg} \mathrm{ha}^{-1}$, respectivamente, com taxa de $2,1 \mathrm{~g}$ e $2,0 \mathrm{~g}$ de $\mathrm{N}$ por $\mathrm{kg}$ de fruto comercial. A produtividade foi maximizada para 52 unidades SPAD. As combinações de formas e estratégias de aplicação de $\mathrm{N}$ não tiveram efeito significativo sobre as variáveis de produção do tomateiro.

Palavras-chave: Solanum lycopersicon, tomate para processamento, crescimento determinado, fertirrigação, estado nutricional, análise econômica.

(Recebido para publicação em 15 de outubro de 2013; aceito em 4 de junho de 2014) (Received on October 15, 2013; accepted on June 4, 2014)

$\mathrm{T}$ he determinate-growth-habit tomato crop, used both for processing and for fresh tomato, is irrigated basically using sprinkler systems in Brazil. Several studies, however, show that the drip irrigation system is feasible, due to the possibility of yield gains above 20\% (Marouelli et al., 2003; Johnstone et $a l ., 2005)$. In the case of indeterminategrowth-habit tomato crop, dripping is probably the most widely used irrigation system (Marouelli et al., 2011a).

The highest tomato yield in drip is possible because water and fertilizers are applied in a gradual and uniform form directly to the roots, in sync with the crop demand, without wetting the plants (Hartz \& Bottoms, 2009; Shedeed et al., 2009; Marouelli et al., 2011a). However, for a greater economic feasibility of the system, it is important to manage the entire production system properly, especially for irrigation and fertigation (Zhang et al., 2010).

Tomato plants properly drip irrigated and fertigated by drip systems become more vigorous and productive, which requires a greater extraction of soil nutrients (Hartz \& Bottoms, 2009). However, as only part of the land is wet, a reduction in the volume of soil explored by the roots occurs
(Marouelli et al., 2011b). Thus, it is necessary to reevaluate the preestablished fertilization practices to maintain adequate fertility in the root zone (Hartz \& Bottoms, 2009). Shedeed et al. (2009) and Zhang et al. (2010) reported that the amount of nutrients required by a particular crop may be quite variable depending on its productive potential and the climatic and soil conditions.

Among the necessary nutrients for the proper development of the tomato crop, nitrogen $(\mathrm{N})$ occupies a prominent position, both in relation to rates and sources required in fertilization, as the 
problems of leaching, volatilization and nutritional deficiency (Rauschkolb \& Hornsby, 1994; Bar-Yosef, 1999).

The forms of $\mathrm{N}$ nitrate $\left(\mathrm{N}-\mathrm{NO}^{-}{ }^{-}\right.$, ammonium $\left(\mathrm{N}-\mathrm{NH}_{4}{ }^{+}\right)$and amide $\left(\mathrm{N}-\mathrm{NH}_{2}\right)$ show differences in costs, leaching potential, soil acidification, volatilization and absorption by plants. Despite the $\mathrm{N}$ in nitrate form be more susceptible to leaching, the use of fertigation may minimize $\mathrm{N}$ leaching, since managed correctly, maintaining a suitable concentration of $\mathrm{N}$ in the upper soil layers. Regarding volatilization, $\mathrm{N}$ loss is usually less than $5 \%$ when applied via drip irrigation (Rauschkolb \& Hornsby, 1994; Jat et al., 2011). The plants can absorb and use substantial quantities of ammonia $\mathrm{N}$, even $\mathrm{N}$ nitric being preferred. Moreover, in tropical regions, other forms of $\mathrm{N}$ are rapidly transformed in soil to nitric $\mathrm{N}$ (Hochmuth \& Smajstrla, 2003). For soil cultivation, Hochmuth \& Smajstrla (2003) recommend that $25 \%$ to $50 \%$ of the total applied $\mathrm{N}$ by fertigation should be in nitrate form, and that up to $40 \%$ should be supplied in pre-planting. In relation to $\mathrm{N}$ doses, some studies recommend from 1.9 to $2.6 \mathrm{~g}$ of $\mathrm{N}$ per $\mathrm{kg}$ of tomato fruits (Bar-Yosef, 1999; Araújo et al., 2007).

Although fertigation has been widely used in the production of fresh tomato, very few studies (Araújo et al., 2007) were carried out based on the Brazilian conditions in order to establish strategies for the application of $\mathrm{N}$ via drip irrigation in tomato plants growing in soil. Among Brazilian producers is common, for example, due to the lack of information, the priority use of nitric sources of $\mathrm{N}$, the supply of the total $\mathrm{N}$ via fertigation, performing fertigations in each irrigation event and the split-applications according to the $\mathrm{N}$ absorption curve. In addition to burdening the cost of production, such strategies typically used by producers complicate the fertigation management and/or may limit the yield of the tomato.

The aim of this work was to establish sources, doses and strategies of $\mathrm{N}$ application in pre-planting and via drip fertigation in determinate-growth-habit tomato crop, prevailing dry winter conditions in Cerrado region of Central
Brazil.

\section{MATERIAL AND METHODS}

Three experiments were carried out at Embrapa Hortaliças, Distrito Federal (15'56'S, 4808'W, altitude $997 \mathrm{~m}$ ), between May and August. According to the Köppen classification, the climate is Cwa (tropical of altitude). The soil was classified as typic distrophic Red Latosol, cerrado stage, clayey texture (60\% clay, $34 \%$ silt and $6 \%$ sand).

Six doses of $\mathrm{N}$ were evaluated in experiment I $(0,80,160,240,320$ and $400 \mathrm{~kg} \mathrm{ha}^{-1}$ ). The experiment II consisted of six combinations of $\mathrm{N}$ forms: nitrate; ammonia; amide; $2 / 3$ nitric $+1 / 3$ ammonia; $2 / 3$ nitric $+1 / 3$ amide; and $1 / 3$ nitric $+2 / 3$ amide. In the experiment III, we evaluated treatments resulting from the combination of three fractions of total nitrogen applied in pre-planting $(0,20$ and $40 \%)$ with two splitting schemes (linear and adjusted absorption curve) of the remainder of $\mathrm{N}$, applied via fertigation throughout the crop cycle.

The soil chemical analysis of the experiments I, II and III, performed in the layer $0-0.20 \mathrm{~cm}$ before the pre-planting fertilizer, indicated respectively: $\mathrm{pH}=$ 6.3, 6.1 and 6.0; $\mathrm{P}=7.9,11.2$ and 6.1 $\mathrm{mg} \mathrm{dm}{ }^{-3} ; \mathrm{K}=243,208$ and $280 \mathrm{mg} \mathrm{dm}^{-3}$; $\mathrm{Na}=20,26$ and $23 \mathrm{mg} \mathrm{dm}^{-3} ; \mathrm{Ca}=5.4$, 3.1 and $4.4 \mathrm{cmol}_{\mathrm{c}} \mathrm{dm}^{-3} ; \mathrm{Mg}=1.7,1.3$ and $1.4 \mathrm{cmol}_{\mathrm{c}} \mathrm{dm}^{-3} ; \mathrm{Al}=0.00 \mathrm{cmol}_{\mathrm{c}} \mathrm{dm}^{-3}$ (all); $\mathrm{H}+\mathrm{Al}=4.2,5.1$ and $5.6 \mathrm{cmol}_{\mathrm{c}} \mathrm{dm}^{-3}$; and organic matter $(\mathrm{OM})=26.3,27.6$ and $34.1 \mathrm{~g} \mathrm{dm}^{-3}$. In the experiment II, the samples were taken from each plot and no significant differences $(\mathrm{p}>0.05)$ for any of the fertility traits evaluated.

The tomato seedlings, hybrid Heinz 9498, were transplanted at a spacing of $0.28 \times 1.20 \mathrm{~m}$ in the first week of May. The plots, with a total individual area of $28.8 \mathrm{~m}^{2}$, were part of a continuous field planting and consisted of four rows of plants of $6.0 \mathrm{~m}$. For the analysis of production, fruits of $5.0 \mathrm{~m}$ of the two center rows of plants were harvested.

The irrigations were performed using a lateral drip line per row of plants, with drip emitters, with a flow rate of 1.2 $\mathrm{L} \mathrm{h}^{-1}$, spaced every $30 \mathrm{~cm}$. The irrigation intervals were of 1 to 2 days during the seedling set and fruiting, and of 3 to 5 days during the other phases of the crop (Marouelli \& Silva, 2007). The irrigation water depths were calculated based on the crop evapotranspiration, determined from a Class A evaporation pan and crop coefficients reported by Marouelli et al. (2011a). The last irrigation in all experiments was performed on the $105^{\text {th }}$ day after the transplantation.

Aiming to control the amount of nutrient and of the sources applied, the water supply to drip pipes of the plots of one treatment was individualized and performed by a PVC pipe of 32 $\mathrm{mm}$ in diameter. The fertilizer solution injection was performed with the aid of a piston-activated hydraulic injection pump installed in the center of each experiment. From the injection pump, the water containing the nutrients was directed to the plots using a control head with a PVC gate valve for each treatment. The fertilizer solution injection rates and the timing of fertigation and irrigation were set to ensure maximum uniformity in the distribution of fertilizers to the entire length of the tubing and drippers.

In all experiments, $250 \mathrm{~kg}$ of $\mathrm{K}_{2} \mathrm{O}$, $600 \mathrm{~kg}$ of $\mathrm{P}_{2} \mathrm{O}_{5}, 160 \mathrm{~kg}$ of $\mathrm{Ca}, 40 \mathrm{~kg}$ of $\mathrm{Mg}, 5 \mathrm{~kg}$ of $\mathrm{Zn}$ and $2 \mathrm{~kg}$ of $\mathrm{B}$ per hectare were applied. Of the total doses, $15 \%$ of the potassium $(\mathrm{K}), 60 \%$ of the calcium $(\mathrm{Ca})$, and $100 \%$ of phosphorus $(\mathrm{P})$, magnesium (Mg) and boron (B) were incorporated in the furrow before transplanting. The supply through fertigation of the remaining doses of $\mathrm{K}$ and $\mathrm{Ca}$ was carried out weekly, applying the same amounts (splitting method) of potassium, between the $2^{\text {nd }}$ and $13^{\text {th }}$ week, and calcium, between the $5^{\text {th }}$ and $12^{\text {th }}$ week of the transplanting.

The total $\mathrm{N}$ applied in the experiments II and III was $160 \mathrm{~kg} \mathrm{ha}^{-1}$. Of this total, $15 \%$ were provided in pre-planting and $85 \%$ weekly via fertigation, following the splitting scheme between the $2^{\text {nd }}$ and $13^{\text {th }}$ week after transplanting; such strategy was also adopted in experiment I. In the experiments I and III, all the N applied in pre-planting was in amidic form, whereas the total applied via fertigation, $75 \%$ was $\mathrm{N}$-amide and $25 \%$ $\mathrm{N}$-nitric. Regardless of the experiment, the first fertigation was performed in the 
$2^{\text {nd }}$ week after transplanting and the final one in the last irrigation.

In the $\mathrm{N}$ split application scheme adopted in the experiment III, the amounts were divided and applied equally between the $2^{\text {nd }}$ and the $13^{\text {th }}$ week. In the absorption curve scheme, the curve proposed by Bar-Yosef (1999) was adjusted to apply $1 \%, 2 \%, 3 \%, 5 \%$, $13 \%, 16 \%, 20 \%, 15 \%, 9 \%$ and $1 \%$ of total $\mathrm{N}$ each $10 \%$ of the crop cycle.

For fertilizations conventionally performed at pre-planting and via fertigation the following nutrient sources were used: potassium nitrate, calcium nitrate, double nitrate of sodium and potassium, ammonium sulfate, urea, potassium sulfate, calcium chloride, hydrated lime, superphosphate, magnesium sulfate, zinc sulfate and borax. In order to minimize costs, $100 \%$ of Ca applied at pre-planting used hydrated lime as a source. Likewise, the priority sources of $\mathrm{N}$ were, in the following order, calcium nitrate, potassium nitrate, double nitrate of sodium and potassium.

The harvest was performed manually in a single operation, when the proportion of ripe fruits has reached at least $95 \%$, similarly to the commonly adopted for processing tomatoes. The variables evaluated in the three experiments were: final stand; leaf and stem biomass; commercial yield; number of commercial fruits per plant; average mass of commercial fruits; percentage of green fruits, rotten fruits and fruits with apical rot, and total soluble solids. The ripe fruits, without serious damage and with a diameter greater than $20 \mathrm{~mm}$, were considered commercial.

The biomass production was determined by drying the shoots of the plants at $60^{\circ} \mathrm{C}$, after removing all the fruits. The production variables were determined from the classification of fruits contained in a sample of approximately $25 \mathrm{~kg}$, after weighing the total production of each plot. The percentage of green fruits and fruits with apical rot were expressed based on number and the rotten fruits based on mass. The total soluble solids content was determined using a bench digital refractometer, from a sample homogenized, by grinding, of fifteen ripe fruits.

Specifically in the experiment I the SPAD index (Soil Plant Analysis Development) of chlorophyll was determined using a portable meter, model Minolta SPAD-502, and the $\mathrm{N}$ content in the leaf dry mass of the tomato crop. The evaluation was performed at 65 days after transplanting, about 10 days before the beginning of the maturation of the fruits. At the time of the evaluations, the $\mathrm{N}$ doses supplied to each treatment totalled $0,48,96,144$, 192 and $240 \mathrm{~kg} \mathrm{ha}^{-1}$. The determinations were performed, between 8 a.m. and 9 a.m., in the third newly formed leaf from the apex of one of the branches of ten plants obtained randomly in each plot. After the chlorophyll readings, leaves (the third newly formed leaf from the apex) were picked from twenty plants of each plot, packed in plastic bags and sent to the Laboratory of Plant Nutrition of Embrapa Hortaliças. The total $\mathrm{N}$ content in the leaf dry mass was determined through micro Kejdhal method, considering the sulfuric acid digestion for obtaining the extract for analysis.

After the harvesting of the experiment II, soil samples were taken $(0-30 \mathrm{~cm})$ in order to determine $\mathrm{pH}$ (water 1:2.5) and the contents of $\mathrm{P}, \mathrm{K}$, $\mathrm{Na}$ (Mehlich 1), Ca, Mg, $\mathrm{Al}$ (potassium chloride), $\mathrm{Al}+\mathrm{H}$ (calcium acetate $\mathrm{pH}$ 7.0) and organic matter (wet oxidation). Twenty samples were taken along the center rows of plants of each plot with the help of a gouge-type auger (25 $\mathrm{mm})$. The samples of each plot were homogenized and sent to the Laboratory of Soil Fertility of Embrapa Hortaliças for analysis.

The experimental design used in all experiments was a randomized block with four replications. The data obtained were subjected to analysis of variance and the variables significantly affected $(\mathrm{p}<0.05)$ by the treatments were analyzed by Duncan test or linear regression (method of orthogonal polynomials). The SPAD indices were related with leaf total $\mathrm{N}$ content and tomato yields by Pearson correlation. The equations in which the leaf $\mathrm{N}$ content and the yield were taken as dependent variables and the SPAD index as independent variable were adjusted. The coefficients of correlation and determination were tested at $1 \%(* *)$ and $5 \%(*)$ significance.

The analysis of economic efficiency involving the treatments of the experiment I and the financial analysis of the total costs with the fertilizers used in the different treatments of the experiment II were performed. For these analyses, the tomato for processing industry in Goiás, the main producing state in Brazil (Carvalho \& Campos, 2009), was considered. The analyses were expressed in hectare.

The expenditures incurred in conducting the culture, excluding the cost of fertilizers, harvesting and transportation of the production, were obtained from the main processed tomato agroindustry in the State of Goias, and totalled $\mathrm{R} \$ 5,580.00 \mathrm{ha}^{-1}$ (partial cost). The average cost with fertilizers was determined based on the amounts used for each treatment and the average price of each fertilizer. The prices of potassium nitrate $\left(\mathrm{R} \$ 3.04 \mathrm{~kg}^{-1}\right)$, calcium nitrate $\left(\mathrm{R} \$ 1.38 \mathrm{~kg}^{-1}\right)$, double nitrate of sodium and potassium $(\mathrm{R} \$ 2.27$ $\left.\mathrm{kg}^{-1}\right)$, ammonium sulphate $\left(\mathrm{R} \$ 0.81 \mathrm{~kg}^{-1}\right)$, urea $\left(\mathrm{R} \$ 1.20 \mathrm{~kg}^{-1}\right)$, potassium sulfate $\left(\mathrm{R} \$ 2.58 \mathrm{~kg}^{-1}\right)$, calcium chloride $(\mathrm{R} \$ 1.92$ $\left.\mathrm{kg}^{-1}\right)$, hydrated lime ( $\left.\mathrm{R} \$ 0.32 \mathrm{~kg}^{-1}\right)$, single superphosphate $\left(\mathrm{R} \$ 0.76 \mathrm{~kg}^{-1}\right)$, magnesium sulfate $\left(\mathrm{R} \$ 0.75 \mathrm{~kg}^{-1}\right)$, zinc sulfate $\left(\mathrm{R} \$ 1.76 \mathrm{~kg}^{-1}\right)$ and borax $(\mathrm{R} \$ 2.15$ $\mathrm{kg}^{-1}$ ) were obtained from quotations taken from three suppliers in the market of Goiás.

The costs of harvesting and transportation were determined based on the yield of fruits delivered in agribusiness (commercial yield), according to integration contracts established with the growers (Carvalho \& Campos, 2009). The costs of the harvesting $\left(\mathrm{R} \$ 20.00 \mathrm{t}^{-1}\right)$ and transportation $\left(\mathrm{R} \$ 30.00 \mathrm{t}^{-1}\right)$ and the price paid to tomato growers ( $\mathrm{R} \$ 187.00$ $\mathrm{t}^{-1}$ ), including awards for quality, were obtained from the processing agribusiness. All costs and prices refer to the 2012 harvest.

The total cost included the partial cost plus the costs of fertilizers, harvesting and transportation. Gross revenue was 
determined by multiplying the price per ton received by the grower with the agribusiness according to the quantity of commercialized fruits (yield). The economic analysis of short-term in the experiment I was performed through determining indicators of net income and rate of return. The net income was determined by subtracting the value of the total cost of gross revenues, whereas the rate of return, which provides a measure of how a monetary unit spent in the activity generates in terms of net income, was obtained by dividing the net income by the total cost.

\section{RESULTS AND DISCUSSION}

During the experiments occurred 47 $\mathrm{mm}$ of rain, the average air temperature was $22.9^{\circ} \mathrm{C}$ and the average relative humidity was $54 \%$. The total irrigation water depth was of $385 \mathrm{~mm}$, a total of 53 irrigations, independent of the experiment.

The duration of the tomato growing cycle was not influenced by the treatments in any of the experiments. The harvestings were carried out on the $115^{\text {th }}$ day after the transplanting in the experiment I, $113^{\text {th }}$ day in the experiment II and $117^{\text {th }}$ in the experiment III.

Experiment I: Evaluation of $\mathrm{N}$ doses

The $\mathrm{N}$ doses applied in the tomato crop affected significantly $(\mathrm{p}>0.05)$ the production of biomass, commercial yield, number of commercial fruits per plant, rotten fruits, SPAD index of chlorophyll and $\mathrm{N}$ content in the leaves. However, the treatments did not have any effect on the final stand of the plants (average of 28.3 thousand ha' ${ }^{-1}$ ), mass of commercial fruits (average of $50.2 \mathrm{~g}$ ), green fruits (average of $4.7 \%$ ), fruits with apical rot (average of $0.1 \%$ ) and total soluble solids (average of $4.6^{\circ}$ Brix).

The production of biomass (stems and leaves) showed a quadratic response to the $\mathrm{N}$ doses, reaching a maximum value for the dose of $339 \mathrm{~kg} \mathrm{ha}^{-1}$ of $\mathrm{N}$ (Figure 1). Above this dose, a slight reduction in biomass was observed, which probably was not due to the reduced growth of plants. Possibly, the significant development of plants occurred in the conditions of high $\mathrm{N}$ availability and adequate irrigation, associated with the prostrate growth habit of the tomato, provided the formation of a more humid microenvironment in the canopy, more favorable for fungi and bacteria, with consequent increase of diseases and rotting of leaves and stems (Carrijo et al., 2004; Parisi et al., 2006; Hartz \& Bottoms, 2009). Similar response was verified by Zhang et al. (2010), who noticed a reduction in the biomass of stems and leaves to $\mathrm{N}$ rates above $285 \mathrm{~kg} \mathrm{ha}^{-1}$ and $293 \mathrm{~kg} \mathrm{ha}^{-1}$ in two years evaluated.

The commercial yield of fruits showed a quadratic response to the doses of $\mathrm{N}$ applied, maximized (133.6 $\mathrm{t} \mathrm{ha}^{-1}$ ) for the dose of $287 \mathrm{~kg} \mathrm{ha}^{-1}$ of $\mathrm{N}$ (Figure 1). As the final stand and the mass of commercial fruits were not affected by treatments, we concluded that the variation of yield was due to the change of the number of commercial fruits per plant, which also showed a quadratic response to the doses of $\mathrm{N}$ (Figure 2). Response similar to the one observed in the present study was reported by Zhang et al. (2010) in Ontario, Canada, which obtained maximum commercial yield ranging from $112 \mathrm{t} \mathrm{ha}^{-1}$ to $139 \mathrm{t}$ $\mathrm{ha}^{-1}$ for doses of $\mathrm{N}$ between $216 \mathrm{tha}^{-1}$ and $305 \mathrm{~kg} \mathrm{ha}^{-1}$.

The necessary dose of $\mathrm{N}$ to achieve maximum biomass of stems and leaves

Table 1. Mean values of $\mathrm{pH}, \mathrm{K}, \mathrm{Na}, \mathrm{Al}, \mathrm{Al}+\mathrm{H}$ and organic matter $(\mathrm{MO})$ in the soil at the end of the tomato cycle according to the nitrogen source used [valores médios de $\mathrm{pH}, \mathrm{K}, \mathrm{Na}, \mathrm{Al}, \mathrm{Al}+\mathrm{H}$ e matéria orgânica (MO) no solo ao final do ciclo de cultivo do tomateiro conforme a fonte de nitrogênio utilizada]. Brasília, Embrapa Hortaliças, 2012.

\begin{tabular}{|c|c|c|c|c|c|c|}
\hline Treatment & pH & $\begin{array}{c}\mathrm{K} \\
\left(\mathrm{mg} \mathrm{dm}^{-3}\right)\end{array}$ & $\begin{array}{c}\mathrm{Na} \\
\left(\mathrm{mg} \mathrm{dm}^{-3}\right)\end{array}$ & $\begin{array}{c}\mathrm{Al} \\
\left(\mathrm{cmol}_{\mathrm{c}} \mathbf{d m}^{-3}\right)\end{array}$ & $\begin{array}{c}\mathrm{Al}+\mathrm{H} \\
\left(\mathrm{cmol}_{\mathrm{c}} \mathbf{d m}^{-3}\right)\end{array}$ & $\begin{array}{c}\mathrm{MO} \\
\left(\mathrm{g} \mathrm{dm}^{-3}\right)\end{array}$ \\
\hline Nitrate & $6.5 \mathrm{a}$ & $240 \mathrm{a}$ & $45 \mathrm{a}$ & $0.00 \mathrm{~d}$ & $2.67 \mathrm{~d}$ & $34.3 \mathrm{c}$ \\
\hline Ammonium & $4.8 \mathrm{~d}$ & $166 \mathrm{c}$ & $19 \mathrm{~b}$ & $0.69 \mathrm{a}$ & $5.41 \mathrm{a}$ & $36.1 \mathrm{ab}$ \\
\hline Urea & $5.3 \mathrm{c}$ & $207 \mathrm{ab}$ & $22 \mathrm{~b}$ & $0.23 \mathrm{~b}$ & $4.35 \mathrm{~b}$ & $34.8 \mathrm{bc}$ \\
\hline $2 / 3$ nitrate $+1 / 3$ ammonium & $5.4 \mathrm{c}$ & $189 \mathrm{bc}$ & $24 \mathrm{~b}$ & $0.20 \mathrm{bc}$ & $4.11 \mathrm{bc}$ & $36.9 \mathrm{a}$ \\
\hline $2 / 3$ nitrate $+1 / 3$ urea & $5.9 \mathrm{~b}$ & $245 \mathrm{a}$ & $27 \mathrm{~b}$ & $0.02 \mathrm{~cd}$ & $3.43 \mathrm{c}$ & $34.6 \mathrm{bc}$ \\
\hline $1 / 3$ nitrate $+2 / 3$ urea & $5.6 \mathrm{bc}$ & $237 \mathrm{a}$ & $27 \mathrm{~b}$ & $0.08 \mathrm{bcd}$ & $3.66 \mathrm{bc}$ & $35.6 \mathrm{abc}$ \\
\hline
\end{tabular}

Mean values followed by same letters in the column do not differ from each other, Duncan $\mathrm{p}>0.05$ (médias seguidas pela mesma letra nas colunas não diferem significativamente entre si pelo teste de Duncan, $\mathrm{p}>0,05$ ).

Table 2. Financial analysis of the costs with fertilizers used in preplant conventional fertilization and via fertigation on the tomato crops according to the nitrogen source used (análise financeira dos custos com fertilizantes utilizados na fertilização convencional em pré-plantio e via fertirrigação do tomateiro conforme a fonte de nitrogênio utilizada). Brasília, Embrapa Hortaliças, 2012.

\begin{tabular}{lcccccc}
\hline Variable & \multirow{2}{*}{ Nitrate } & \multirow{2}{*}{ Ammonium } & \multirow{2}{*}{ Urea } & $\begin{array}{c}\mathbf{2 / 3} \text { nitrate }+ \\
\mathbf{1 / 3} \text { ammonium }\end{array}$ & $\begin{array}{c}\mathbf{2 / 3} \text { nitrate }+ \\
\mathbf{1 / 3} \text { urea }\end{array}$ & $\begin{array}{c}\mathbf{1 / 3} \text { nitrate }+ \\
\mathbf{2 / 3} \text { urea }\end{array}$ \\
\hline Cost $\left(\mathrm{R} \$\right.$ ha $\left.^{-1}\right)$ & $5,501.01$ & $5,486.51$ & $5,274.87$ & $5,433.28$ & $5,362.73$ & $5,245.29$ \\
Reduction of cost $(\%)^{*}$ & 0.0 & 0.3 & 4.1 & 1.2 & 2.5 & 4.6 \\
\hline
\end{tabular}

*Relative to the treatment with nitrate (relativo ao tratamento com nitrato). 
was $18 \%$ greater than that for maximum fruit yield, showing that the fruit production is not directly balanced with vegetative biomass. According to Zhang et al. (2010), the vigorous vegetative growth, especially during the second half of the stage of tomato fruiting, can occur at the expense of fruit production, due to competition for carbohydrates which are produced during photosynthesis.

Considering only the doses of $\mathrm{N}$ between $80 \mathrm{~kg} \mathrm{ha}^{-1}$ and $320 \mathrm{~kg} \mathrm{ha}^{-1}$, which comprise respectively the treatment with the lowest dose of $\mathrm{N}$ and the highest dose for which an increasing of commercial yield could be noticed, the relations between $0.7 \mathrm{~g}$ and 2.4 $\mathrm{g}$ of $\mathrm{N}$ per $\mathrm{kg}$ of commercial tomato fruits produced were obtained. For the dose of $\mathrm{N}$ in which the fruit yield was maximized, the ratio was $2.1 \mathrm{~g} \mathrm{~kg}^{-1}$ (Figure 1), which is similar to the one reported by Bar-Yosef (1999) to obtain the maximum yield of tomato (2.0-2.5 g $\left.\mathrm{kg}^{-1}\right)$. Zhang et al. (2010), in three years of study, verified that it was necessary to apply from 1.7 to $2.7 \mathrm{~g}$ of $\mathrm{N}$ per $\mathrm{kg}$ of commercial fruits to maximize the yield of determinate-growth-habit tomato crop fertigated by drip. The variations verified among different studies can be partially explained, according to Hartz \& Bottoms (2009), due to the residual of $\mathrm{NO}_{3}-\mathrm{N}$ and the mineralization of organic matter throughout the growing season, besides differences in nutritional requirements among the cultivars used.

The rot of fruits increased linearly with the increase of doses of $\mathrm{N}$ to the crop, varying between $0.8 \%$ and $2.5 \%$ (Figure 2). Despite the reduced number of rotten fruits, the authors verified that the higher incidence of fruit rot was directly related to the higher vegetative growth of plants fertilized with higher doses of N. According to Carrijo et al. (2004), plants with vigorous vegetative growth, mainly due to excess of $\mathrm{N}$, are more susceptible to disease and fruit rot.

On the total soluble solids content, which was not affected by doses of $\mathrm{N}$ up to $400 \mathrm{~kg} \mathrm{ha}^{-1}$, Hartz \& Bottoms (2009) also did not verify the effect of increasing doses of $\mathrm{N}$ (90-330 $\mathrm{kg} \mathrm{ha}^{-1}$ ) in soluble solids content of fertigated tomatoes.

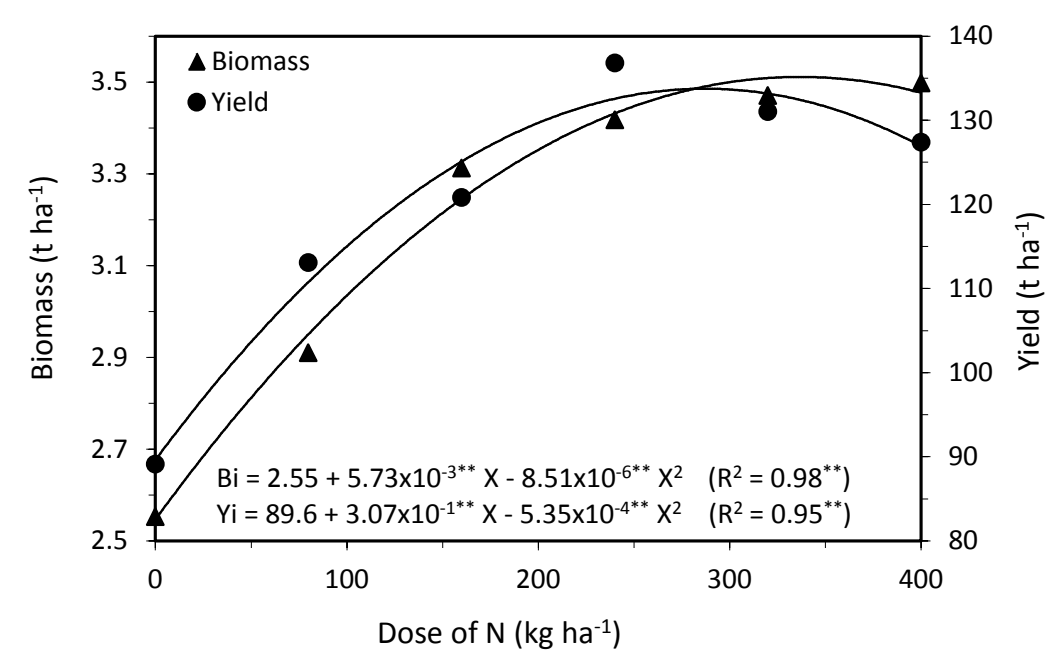

Figure 1. Response functions for biomass and marketable fruit yield according to the dose of nitrogen $(\mathrm{N})$ applied to the tomato crop [funções de resposta para biomassa e produtividade comercial de frutos conforme a dose de nitrogênio $(\mathrm{N})$ aplicada ao tomateiro]. Brasília, Embrapa Hortaliças, 2012.

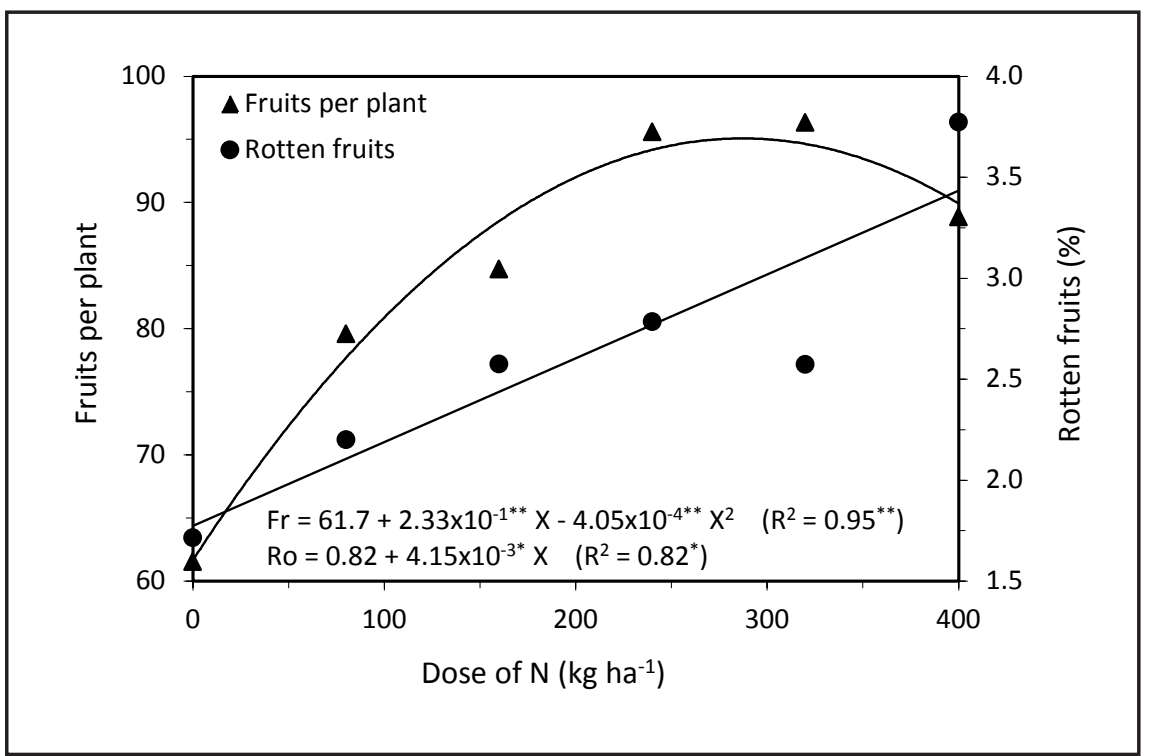

Figure 2. Response functions for fruits per plant and rotten fruits according to the dose of nitrogen $(\mathrm{N})$ applied to the tomato crop [funções de resposta para frutos por planta e frutos podres conforme a dose de nitrogênio $(\mathrm{N})$ aplicada ao tomateiro]. Brasília, Embrapa Hortaliças, 2012.

The SPAD index and the $\mathrm{N}$ content in the $3^{\text {rd }}$ leaf of the tomato crop increased linearly with the doses of $\mathrm{N}$ applied (Figure 3). By the Pearson test, a positive and highly significant linear correlation $(0.873 * *)$ between SPAD index and leaf $\mathrm{N}$ content, was verified allowing the adjustment of a linear equation between the two variables
(Figure 4). This fact indicates that the SPAD index can be used to characterize the nutritional status of the total $\mathrm{N}$ of the tomato crop, quickly, nondestructively and into the field, according to what was also verified by Ferreira et al. (2006) in indeterminate-growth-habit tomato crop.

The significant correlation $(0.472 *)$ 
was also verified between SPAD index and commercial yield. By the adjusted quadratic equation (Figure 4), we noticed that the index of 52 SPAD units maximized the yield, whereas Ferreira et al. (2006) obtained indices between 41 and 52 for indeterminate-growth-habit tomato crop. According to Zotarelli et al. (2003), variations between critical SPAD indexes can occur due to various factors, as plant age, cultivar used and growing conditions.

Similarly to that observed for fruit yield, both economic efficiency indicators evaluated showed a quadratic response for the doses of $\mathrm{N}$ (Figure $5)$. The net income was maximized $\left(\mathrm{R} \$ 7,208.63 \mathrm{ha}^{-1}\right)$ for the dose of 270 $\mathrm{kg} \mathrm{ha}^{-1}$ of $\mathrm{N}$, whereas the higher rate of return (0.41) occurred for the dose of $262 \mathrm{~kg} \mathrm{ha}^{-1}$, which represents a reduction of $6 \%$ and $9 \%$, respectively, in the dose of $\mathrm{N}$ which resulted higher yield of the fruits. From the doses of $\mathrm{N}$ that maximized both indicators of economic efficiency and the adjusted regression equation for yield, we obtained the ratio of $2.0 \mathrm{~g}$ of $\mathrm{N}$ per $\mathrm{kg}$ of tomatoes produced which is associated to the doses of $\mathrm{N}$ responsible for maximizing both the net income and the rate of return of the tomato crop.

For the conditions under which the present work was carried out the maximum yield of the commercial fruits (133.6 $\mathrm{t} \mathrm{ha}^{-1}$ ) was obtained at the dose of $287 \mathrm{~kg} \mathrm{ha}^{-1}$ of N. On the other hand, higher net income was calculated for $270 \mathrm{~kg} \mathrm{ha}^{-1}$ of $\mathrm{N}$, which represents a rate of $2.0 \mathrm{~g}$ of $\mathrm{N}$ per $\mathrm{kg}$ of commercial fruits. The SPAD index of chlorophyll can be used for a quick evaluation in field conditions on the nutritional status of the tomato crop, considering 52 units as the critical level to maximize fruit yield.

Experiment II: Evaluation of combinations of $\mathrm{N}$ forms

None of the evaluated variables of production and quality of fruit was significantly affected $(p>0.05)$ by the treatments in experiment II. The mean values observed were: final stand of 29.5 thousand plants per hectare; biomass production of $2.89 \mathrm{t} \mathrm{ha}^{-1}$; commercial yield of $119.5 \mathrm{t} \mathrm{ha}^{-1} ; 79.8$ commercial fruits per plant, commercial fruit mass of $50.8 \mathrm{~g} ; 2.9 \%$ of green fruits; $2.8 \%$ of

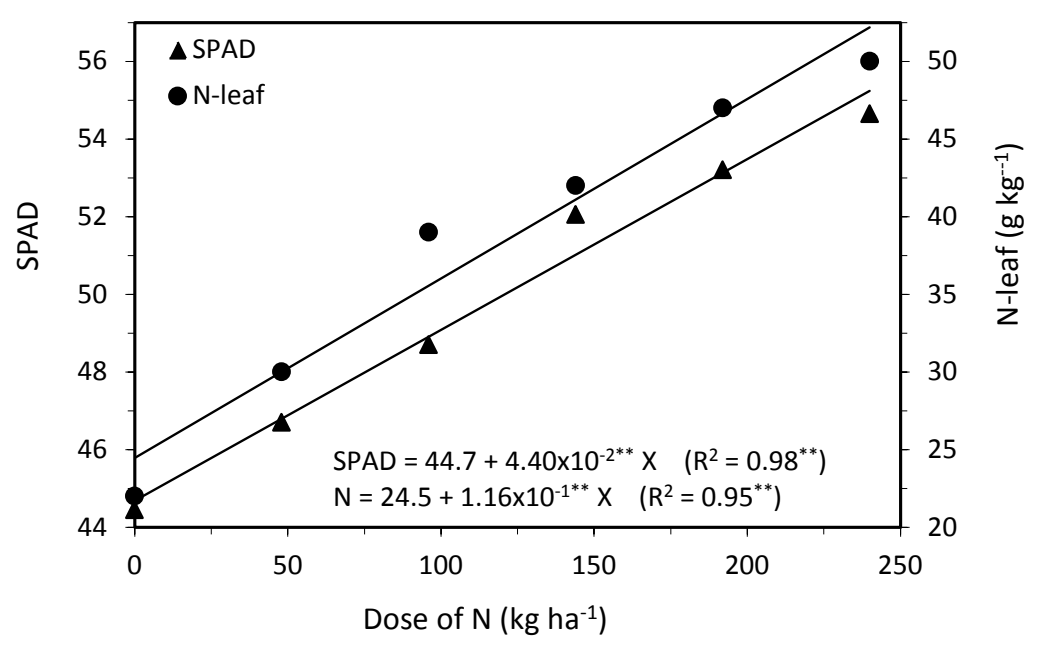

Figure 3. Response functions for SPAD chlorophyll index and levels of nitrogen $(N)$ in tomato leaf according to the dose of $\mathrm{N}$ applied until 65 days after transplantation [funções de resposta para índice SPAD de clorofila e teor de nitrogênio $(\mathrm{N})$ na folha do tomateiro conforme a dose de $\mathrm{N}$ aplicada até 65 dias após o transplante]. Brasília, Embrapa Hortaliças, 2012.

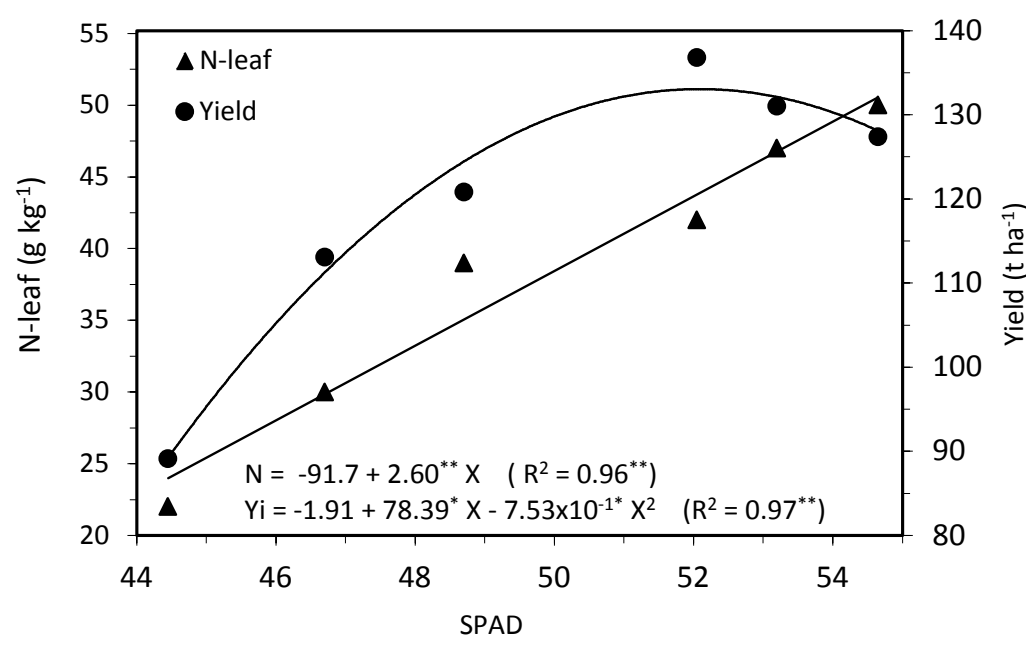

Figure 4. Correlation functions between SPAD chlorophyll index readings and levels of nitrogen $(\mathrm{N})$ in the leaf, at 65 days after transplantation, and between SPAD index readings and tomato yield [funções de correlação entre índices SPAD de clorofila e teores de nitrogênio (N) na folha, aos 65 dias após o transplante, e entre indices SPAD e produtividades de tomateiro]. Brasília, Embrapa Hortaliças, 2012.

rotten fruit; $0.2 \%$ of fruits with apical rot and total soluble solids of $5.2^{\circ}$ Brix.

Unlike the results obtained in this study, Pill \& Lambeth (1980) verified a reduction of the number of fruits per plant and of yield of the tomato crop and an increase of the apical rot when $\mathrm{N}$-ammonia was used in comparison to N-nitric. In this condition, according to Passam et al. (2007), a decrease in calcium absorption can happen, provoked by the high $\mathrm{NH}_{4}^{+}$ concentration which, probably, did not happen, significantly, in this present work. The disagreement involving both studies may have resulted due to the fact that the experiment of Pill \& Lambeth (1980) was carried out in substrate and 


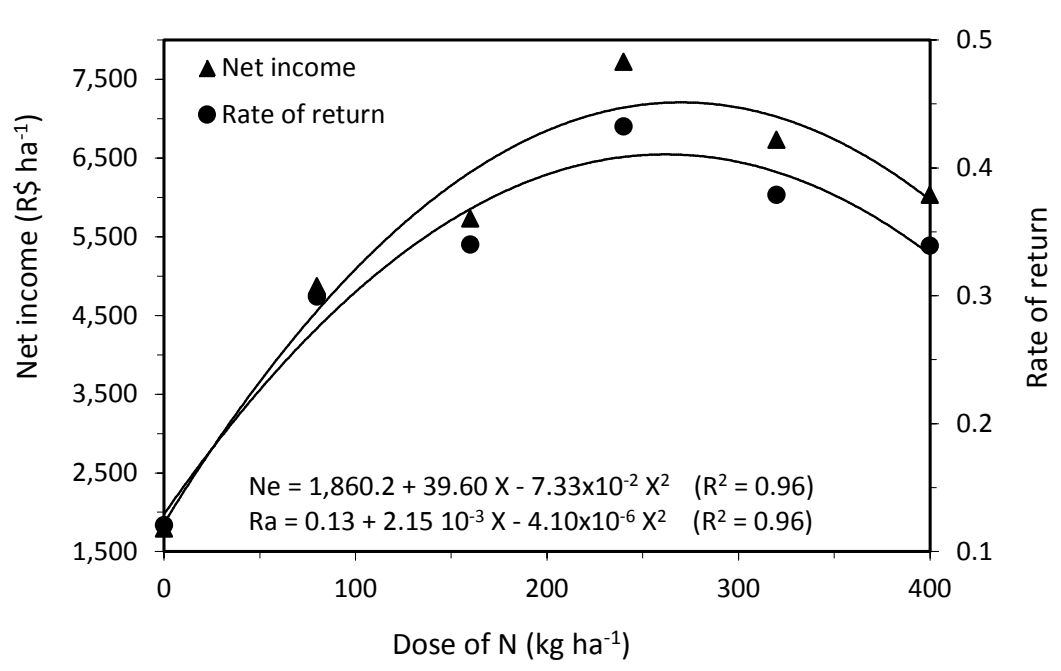

Figure 5. Response functions for net income and rate of return according to the dose of nitrogen $(\mathrm{N})$ applied to the tomato crop [funções de resposta para renda líquida e taxa de retorno, conforme a dose de nitrogênio $(\mathrm{N})$ aplicada ao tomateiro]. Brasília, Embrapa Hortaliças, 2012.

mild weather conditions, which affects distinctly the nitrogen dynamics in the soil and in the plant (Rauschkolb \& Hornsby, 1994). Subsequently, Claussen (2002) noted that the exclusive or predominant use of $\mathrm{N}$-ammonia in the nutrient solution resulted in lower growth and yield of hydroponic tomato crop, occasioned by its great impact on the rhizosphere $\mathrm{pH}$.

In relation to the variables of soil fertility evaluated at the end of the experiment, the $\mathrm{N}$ form used affected significantly the $\mathrm{pH}$ and the contents of $\mathrm{K}, \mathrm{Na}, \mathrm{Al}, \mathrm{Al}+\mathrm{H}$ and organic matter (Table 1), but did not affect the contents of P (average of $102 \mathrm{mg} \mathrm{dm}^{-3}$ ), Ca (average of $4.9 \mathrm{cmol}_{\mathrm{c}} \mathrm{dm}^{-3}$ ) and $\mathrm{Mg}$ (average of $1.8 \mathrm{cmol}_{\mathrm{c}}^{\mathrm{c}} \mathrm{dm}^{-3}$ ).

As expected, the higher the fraction of $\mathrm{N}$-amide and, mainly, of $\mathrm{N}$-ammonia in the total amount of $\mathrm{N}$ applied, the lower was the $\mathrm{pH}$ and higher contents of $\mathrm{Al}$ and $\mathrm{Al}+\mathrm{H}$ in the soil at the end of the tomato crop cycle, confirming that the ammonia and amidic sources of $\mathrm{N}$ acidify the soil (Rauschkolb \& Hornsby, 1994; Claussen, 2002). The treatments containing $\mathrm{N}$-ammonia had lower $\mathrm{K}$ contents, but there were no significant differences observed between the treatments with $\mathrm{N}$-nitric and $\mathrm{N}$-amidic. The reduction in $\mathrm{K}$ content was not probably due to the absorption by the tomato crop, because in conditions of $\mathrm{NH}_{4}^{+}$high concentrations, a reduction in $\mathrm{K}^{+}$absorption is noticed. One possible explanation, considering that all the $\mathrm{N}$-ammonia had ammonium sulphate as a source, is that $\mathrm{NH}_{4}^{+}$cation had displaced $\mathrm{K}^{+}$from the soil exchange complex, which, may have reacted with the anion $\mathrm{SO}_{4}^{2-}$ forming a neutral ion pair, $\mathrm{K}_{2} \mathrm{SO}_{4}$, that due to its neutrality has great mobility in the soil profile. The treatment with $100 \%$ of $\mathrm{N}$-nitric showed higher Na content in the soil due to the use of double nitrate of sodium and potassium as sources of $\mathrm{N}$-nitric, no differences in $\mathrm{Na}$ contents of all other treatments being found. An increase in $\mathrm{pH}$ and a reduction in the potential acidity $(\mathrm{H}+\mathrm{Al})$, due to the $\mathrm{N}$-nitric absorption, was noticed. Although a major effect in the form of $\mathrm{N}$ on the final organic matter content in the soil had been verified, higher contents were noticed in the treatments which received $\mathrm{N}$-ammonia.

The variation in cost among fertilizer treatments was less than 5\% (Table 2 ). The highest cost occurred in the $100 \% \mathrm{~N}$-nitric treatment ( $\$ 5,501.01$ $\mathrm{ha}^{-1}$, which practically did not differ from the $100 \% \mathrm{~N}$-ammonia treatment $\left(\mathrm{R} \$ 5,486.51 \mathrm{ha}^{-1}\right)$. The treatments $1 / 3$ $\mathrm{N}$-nitric $+2 / 3 \mathrm{~N}$-amide and $100 \%$ $\mathrm{N}$-amide showed the lowest cost, respectively, $4.6 \%$ and $4.1 \%$ lower than the cost in $100 \% \mathrm{~N}$-nitric treatment. The insignificant difference in costs with fertilizers between treatments $100 \% \mathrm{~N}$-amide and $1 / 3 \mathrm{~N}$-nitric $+2 / 3$ $\mathrm{N}$-amide, despite the higher cost of the sources of N-nitric, is basically due to the high relative cost of calcium chloride, the only source of Ca used via fertigation in the treatment with $100 \%$ $\mathrm{N}$-amide. In the case of the treatment 1/3 N-nitric $+2 / 3 \mathrm{~N}$-amide, significant part of the Ca supplied by fertigation had calcium nitrate as source, which also provided $\mathrm{N}$-nitric.

As the yield of the tomato crop was not affected by the source of $\mathrm{N}$ applied, we concluded that for the conditions in which the study was carried out, the treatments $1 / 3 \mathrm{~N}$-nitric $+2 / 3 \mathrm{~N}$-amide and $100 \% \mathrm{~N}$-amide showed financial return slightly higher than the other treatments, due to the lower cost of the fertilizers (Table 2). However, the continuous and exclusive use of a single form of $\mathrm{N}$-nitric, especially $\mathrm{N}$-ammonia and $\mathrm{N}$-amide, may, under certain conditions, affect the subsequent crop production such as, for example, promote the soil acidification (BarYosef, 1999). Even the nitrate form should not be used continuously and exclusively since it can lead to a progressive increase of the rhizosphere $\mathrm{pH}$ values above 8 , which will reduce the availability of phosphorus and micronutrients (Jat et al., 2011). In the case of the tomato crop, it is common, however, not to grow this crop for more than two continuous years in the same area due to the higher risk of soil-borne diseases.

Although no effect of treatments on the quality of tomato fruits has been observed, at least as regards to content of soluble solids, the use of more than one form of $\mathrm{N}$, nitric plus ammoniacal or amidic, it is frequently recommended aiming better quality fruits. According to Flores et al. (2003), the inclusion of part of $\mathrm{N}$ in ammoniacal form improves the fruit quality by increasing the content of sugars and organic acids in relation to the exclusive use of N-nitric, whereas Heeb et al. (2005) verified that the use of reduced forms of $\mathrm{N}$, ammoniacal and amidic, improve the flavor and aroma of 
the tomatoes. For the fertigation in soil, Hochmuth \& Smajstrla (2003) suggest to provide about $50 \%$ of the total $\mathrm{N}$ in the nitric form, considering that in tropical regions, the amount may be reduced to $25 \%$.

Even though no significant differences in yield between $\mathrm{N}$ forms and combinations of forms used were noticed, the authors suggest, for similar conditions verified in the present study, applying 1/3 N-nitric + $2 / 3 \mathrm{~N}$-amide for the following reasons: slightly higher financial return than the other combinations of forms of $\mathrm{N}$ due to the lower cost of fertilizers; less potential for soil acidification in relation to the exclusive use of $\mathrm{N}$-amidic or N-ammonia; and N-nitric is the preferred form absorbed by plants, but it is susceptible to leaching.

Experiment III: Evaluation of the splitting schemes of $\mathrm{N}$

Similarly to experiment II, none of the variables was significantly affected $(p>0.05)$ by splitting schemes of $N$. The means observed were: final stand of 28.0 thousand plants per hectare; biomass production of $2.77 \mathrm{t} \mathrm{ha}^{-1}$; commercial yield of $116.4 \mathrm{t} \mathrm{ha}^{-1} ; 81.3$ commercial fruits per plant, commercial fruit mass of $51.2 \mathrm{~g} ; 4.1 \%$ of green fruits; $2.91 \%$ of rotten fruit; $0.2 \%$ of fruits with apical rot and total soluble solids of $5.1^{\circ}$ Brix. Thus, the supply of up to $40 \%$ at pre-planting and the splitting of the remaining $\mathrm{N}$ via fertigation, following the linear and adjusted absorption curve scheme, did not affect the yield of the tomato crop.

The non-significant effect of treatments on the production variables of the tomato crop, even under conditions without any supply of $\mathrm{N}$ at pre-planting, can be partially explained by the initial $\mathrm{N}$ availability in the soil and the amounts of $\mathrm{N}$ applied via fertigation after the second week after transplantation being enough to meet the demand of $\mathrm{N}$ by plants in early development. On the other hand, a reduction of yield, even when $40 \%$ of the amount of $\mathrm{N}$ was supplied in a conventional form at pre-planting, was not verified, in agreement to Hochmuth \& Smajstrla (2003), who recommend, depending on soil type, applying up to $40 \%$ of total $\mathrm{N}$ at pre-planting. In this case, the correct irrigation management, without applying excess water, may have been crucial to minimize the leaching of $\mathrm{N}$ (Jat et al., 2011). Additionally, according to Rauschkolb \& Hornsby (1994), the supply of $\mathrm{N}$ at pre-planting incorporated into soil and via drip fertigation substantially minimize $\mathrm{N}$ losses by volatilization. The fact that the soil used in this study has $60 \%$ clay and organic matter content of $34.1 \mathrm{~g}$ $\mathrm{dm}^{-3}$ is also important to add (Shedeed et al., 2009).

Although no significant variation in the tomato yield with application of up to $40 \%$ of total $\mathrm{N}$ at pre-planting and the splitting scheme of the remaining $\mathrm{N}$ via fertigation was observed, the authors suggest, even for soils with clay and organic matter contents higher than those found in the present study, applying between $10 \%$ and $20 \%$ of $\mathrm{N}$ at pre-planting and the remainder via fertigation, through splitting scheme in equal amounts throughout the growing cycle of the tomato crop. This strategy has three main advantages: provides sufficient $\mathrm{N}$ for the initial development of the plants, especially in soils with low $\mathrm{N}$ availability; minimizes $\mathrm{N}$ losses by leaching, either by excessive irrigation or rainfall occurrence; and facilitates the management since doses of $\mathrm{N}$ are equal to each fertigation.

\section{ACKNOWLEDGEMENTS}

The first author acknowledges the fellowship granted by CNPq.

\section{REFERENCES}

ARAÚJO C; FONTE PCR; SEDIYAMA CS; COELHO MB. 2007. Critérios para a determinação da dose de nitrogênio a ser aplicada no tomateiro em ambiente protegido. Horticultura Brasileira 25: 327-332.

BAR-YOSEF B. 1999. Advances in fertigation. Advances in Agronomy 65: 1-77.

CARRIJO AO; SOUZA RB; MAROUELLI WA; ANDRADE RJ. 2004. Fertirrigação de hortaliças. Brasília: Embrapa Hortaliças. 13p. (Circular Técnica, 32).

CARVALHO CRR; CAMPOS FR. 2009. Análise dos aspectos econômicos e ambientais da cadeia agroindustrial do tomate no Estado de Goiás. Boletim Goiano de Geografia 29:
163-178.

CLAUSSENW.2002. Growth, water use efficiency, and proline content of hydroponically grown tomato plants as affected by nitrogen source and nutrient concentration. Plant and Soil 247: 199-209.

FERREIRA MMM; FERREIRA GB; FONTES PCR; DANTAS JP. 2006. Índice SPAD e teor de clorofila no limbo foliar do tomateiro em função de doses de nitrogênio e da adubação orgânica, em duas épocas de cultivo. Revista Ceres 53: 83-92.

FLORES P; NAVARRO JM; CARVAJAL M; CERDÁ A; MARTÍNEZ V. 2003. Tomato yield and quality as affected by nitrogen source and salinity. Agronomie 23: 249-256.

HARTZ TK; BOTTOMS TG. 2009. Nitrogen requirements of drip irrigated processing tomatoes. Hortscience 44: 1988-1993.

HEEB A; LUNDEGÅRDH B; ERICSSON T; SAVAGE GP. 2005 Nitrogen form affects yield and taste of tomatoes. Journal of the Science of Food and Agriculture 85: 1405-1414.

HOCHMUTH GJ; SMAJSTRLA AG. 2003. Fertilizer application and management for micro (drip)-irrigated vegetables. Gainesville: University of Florida/Cooperative Extension Service/Institute of Food and Agricultural Sciences. 33p.

JAT RA; WANI SP; SAHRAWAT KL; SINGH P; DHAKA BL. 2011. Fertigation in vegetable crops for higher productivity and resource use efficiency. Indian Journal of Fertilizer 7: 22-37.

JOHNSTONE PR; HARTZ TK; LESTRANGE M; NUNEZ JJ; MIYAO EM. 2005. Managing fruit soluble solids with late-season deficit irrigation in drip-irrigated processing tomato production. HortScience 40: 1857-1861.

MAROUELLI WA; CARRIJO OA; SOUZA RB; SILVA WLC. 2011a. Irrigação e fertirrigação na cultura do tomate. In: SOUSA VF; MAROUELLI WA; COELHO EF; PINTO JM; COELHO FILHO M. Irrigação e fertirrigação em fruteiras e hortaliças. Brasília: Embrapa Informação Tecnológica. p.739-769.

MAROUELLI WA; MEDEIROS MA; SOUZA RF; RESENDE FV. 2011b. Produção de tomateiro orgânico irrigado por aspersão e gotejamento, em cultivo solteiro e consorciado com coentro. Horticultura Brasileira 29: 429-434.

MAROUELLI WA; SANT'ANA RR; SILVA WLC; MORETTI CL; VILELA NJ. 2003. Avaliação técnica e econômica do espaçamento de gotejadores em tomateiro para processamento cultivado em fileiras simples e duplas. Horticultura Brasileira 21: 202-206.

MAROUELLI WA; SILVA WLC. 2007. Water tension thresholds for processing tomatoes under drip irrigation in Central Brazil. Irrigation Science 25: 411-418.

PARISI M; GIORDANO I; PENTANGELO A; D'ONOFRIO B; VILLARI G. 2006. Effects of different levels of nitrogen fertilization on yield and fruit quality in processing tomato. Acta Horticulturae 700: 129-132.

PASSAM HC; KARAPANOS IC; BEBELI PJ; SAVVAS DA. 2007. Review of recent research on tomato nutrition, breeding and post-harvest 
technology with reference to fruit quality. The European Journal of Plant Science and Biotechnology 1: 1-21.

PILL WG; LAMBETH VN. 1980. Effects of soil water regime and nitrogen form on blossom-end rot, yield, water relations, and elemental composition of tomato. Journal of the American Society for Horticultural Science 105: 730-734.

RAUSCHKOLB RS; HORNSBY AG. 1994.
Nitrogen management in irrigated agriculture. New York: Oxford University Press. 251p. SHEDEED SI; ZAGHLOUL SM; YASSEN AA. 2009. Effect of method and rate of fertilizer application under drip irrigation on yield and nutrient uptake by tomato. Ozean Journal of Applied Sciences 2: 139-147.

ZHANG TQ; TAN CS; LIU K; DRURY CF; PAPADOPOULOS AP; WARNER J. 2010. Yield and economic assessments of fertilizer nitrogen and phosphorus for processing tomato with drip fertigation. Agronomy Journal 102: 774-780.

ZOTARELLI L; CARDOSO EG; PICCININ JL; URQUIAGA S; BODDEY RM; TORRES E; ALVES BJR. 2003. Calibração do medidor de clorofila SPAD-502 para avaliação do conteúdo de nitrogênio do milho. Pesquisa Agropecuária Brasileira 38: 1117-1122. 